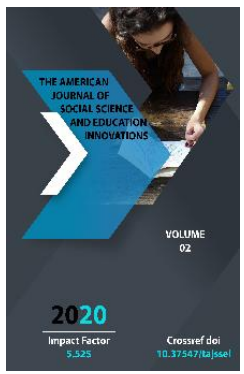

\title{
Attitudes And Social Protection Of People With Disabilities During The Fight Against Fascism
}

\author{
Jummagul Nomazovna Abdurakhmanova \\ Department of History, PhD., Chirchik State Pedagogical Institute of Tashkent region, \\ Uzbekistan
}

Copyright: Original content from this work may be used under the terms of the creative commons attributes 4.0 licence.

\section{ABSTRACT}

This article provides information about the post-disability lifestyle of our compatriots, soldiers and officers who returned to Uzbekistan with disabilities, who were wounded at the front and went to fight against fascism. The article also covers the state of the social protection system during the Second World War and the issues of social protection for the disabled. The article also highlights the humane, caring and tolerant qualities of the people of Uzbekistan towards people with disabilities.

\section{KEYWORDS}

World War II, fascism, back front, supply base, wellness center, disabled, hospital, social protection, social assistance, pension, tolerance, care.

\section{INTRODUCTION}

\section{RELEVANCE}

Man began to live on earth, having experienced many hardships throughout his life. It is these wars that have inflicted terrible suffering on human lives. Any war also leaves a deep tragic mark on people's lives.

Mankind has experienced many wars throughout its history, the most horrific of which is World War II, the tragedy of the twentieth century. The war lasted 61 years, covering 61 countries, $80 \%$ of the world's population, and resulted in the deaths of more than 50 million people.

Along with the 15 republics of the former USSR, Uzbekistan was plunged into a war against fascism during World War II.

During the Second World War, the people of Uzbekistan began to fight against fascism with a genuinely high love for their country and hatred for the enemy who invaded their 
homeland. The people felt that they were the only force capable of stopping and throwing the enemy. The people of Uzbekistan have once again demonstrated their patriotism during the difficult war.

During the war, Uzbekistan became one of the main supply bases of the front. The existing manufacturing enterprises in the republic were relocated to the military sphere, and all opportunities for the front and victory were mobilized. In turn, Uzbekistan has become one of the health centers. The people of Uzbekistan have once again demonstrated such qualities as humanity, care and tolerance in receiving, treating and reviving the wounded on the front. In turn, our people have made a significant contribution to the victory in the Second World War, which had the worst consequences in the history of the world.

Although more than 75 years have passed since the victory in the Second World War against fascism, the wounds inflicted by the war, the severe consequences of the war will never be forgotten. It warns the present generation of the horrors of war. It is always important to study the hardships of the Second World War, the heavy losses and suffering of our people, the courage and fortitude of our people during the war against fascism, the humanity, care and tolerance in difficult times.

\section{METHODS}

The article is based on the principles of generally accepted historical methods historical, comparative and logical analysis, consistency, objectivity, millions of people evacuated from the frontline, wounded on the battlefield and brought to health centers in Uzbekistan were provided with high humanitarian assistance of our people. The necessary assistance provided to the disabled during these years, the employment of war invalids, measures to organize their labor, the historical aspects of their social protection, the role of tolerance in the socio-political and spiritual processes of the most difficult years.

The subject of World War II has always been one of the most important topics to be studied by scholars and researchers. The tragedy of the Second World War, the struggle of millions of people of different nationalities against fascism, their unparalleled courage and perseverance, the heroism and devotion of the people of Uzbekistan at the front and back, the hardships of the war, the consequences of the war have been studied by many foreign and Uzbek researchers. In particular, many research papers, monographs, works, essays and articles have been published on the fascist efforts of reactionary forces to establish their dominance in the world, the endurance of our people during the war, their confidence in victory, their great contribution to victory.

It is expedient to study research works, scientific works, pamphlets, articles and essays on the heroism and self-sacrifice of the people during the Second World War and their great contribution to the victory in the following groups:

1. Articles and essays published in newspapers and magazines in 1941-1945;

2. Research work, published works, pamphlets and articles in 1946-1991;

3. Research works, monographs, scientific articles, works created during the years of independence.

The first group includes works on the war years published by M. Yuldashev, Yu. Zufarov, M.Rubnstein, E.Tarle, M. Rasulov. It is also possible to include speeches of $\mathrm{Y}$. Akhunbobev and $U$. Yusupov, leaders of Uzbekistan during the war years. Because their speeches and lectures also contain valuable ideas about that period. 
The second group includes research works and many works created by T.Juraev, F.Salahutdinov, M.Hasanov, M.losko, H.Tajiboev, L.Yusupov and many other researchers.

The third group includes H. Ziyaev, D. Bobojonova, A. Razzokov, N. Bobojonova, M. Saipova, H. Bobojonov and many other historians, researchers, research articles and pamphlets.

One of the most important issues today is to convey to the next generation the great work done by our people in the wars against fascism, the truth of that time, to inform them of the grave consequences of the war, to conduct scientific research on these years.

In World War II, the multi-ethnic people of Uzbekistan made a worthy contribution to the victory over fascism with their unparalleled courage and fortitude on the battlefields and behind the front lines. "We need to study more deeply the life, courage and perseverance of our compatriots who contributed to the Great Victory, and create scientific research, works of art, films and performances about it. Our young people need to know and appreciate the courage of those who have lived in peace and happiness for almost 75 years without the scourge of war. "[1]

\section{RESEARCH RESULTS}

We all know that World War II is one of the greatest tragedies in human history. The Second World War caused the most horrible and bloody massacres not only to the peoples of the world, but also to the Uzbek people, leaving deep pain and suffering in the hearts of our people. During the turbulent years of the war, our people fought valiantly against fascism, showed courage on the bloody battlefields, worked behind the front lines and made an invaluable contribution to the victory.
"Our people will never forget the suffering, loss and innumerable casualties of this war," he said. On the eve of the war, Uzbekistan had a population of 6.5 million, of which more than 1.5 million were mobilized. This was $22 \%$ of our population at that time, and $40-42 \%$ of the working population " $[2,318]$.

During the war against fascism, "more than 500,000 Uzbek soldiers - one in three of those mobilized to the front - were killed, and more than 60,000 of our compatriots returned with disabilities." [3, 319]

Along with the supply of products for the front, Uzbekistan has also become one of the health centers. Soldiers and officers wounded in the battles were sent to Uzbekistan. During the war, 113 military hospitals were located in Uzbekistan, sponsored by more than 750 local enterprises, institutions, collective farms and state farms. [4, 8]. “In 1941-1945, our country became a huge hospital in the former Soviet Union. Thousands of fighters were treated here and returned to the fronts of war and labor. " [5, 320]

The Uzbeks did their best to help thousands of soldiers and officers recover. In turn, the recovered warriors were escorted to the front or placed to work in enterprises. In addition to those who were cured, those who were disabled also made up the majority.

During these years, the necessary assistance was provided to the disabled. Employment measures were also taken according to their situation. They, in turn, worked in industrial enterprises, agriculture, various organizations. On October 24, 1944, the Council of People's Commissars of the USSR passed a resolution on the employment of war invalids and the improvement of the work of cooperatives for the disabled. [6, 30]. The resolution calls for the consideration and implementation of an action plan to expand the employment of war invalids and improve their labor organization. 
Not only the employment of the disabled, but also their social protection was important. Because among the disabled, there were those who were able to work as well as those who were not able to work at all. Such people needed social protection, registration by social security authorities, and the appointment of benefits to them. During these years, along with the issue of pensions, one of the most important issues was the employment of people with disabilities of groups I, II and III in various sectors of the economy through vocational training for a certain period of time. There were even instructions to set up special workshops and cooperatives for the disabled to work at home.

In 1941-1945, the most important issue of social protection for the disabled was the issue of pensions. If we look at the figures for these years, the reports of the social security authorities on January 1, 1945 show that a total of 62,795 war invalids, including 1,037 people with group I disabilities, 27,413 people with group II disabilities, and 34,345 people with group III disabilities received benefits. [7, 2].

During these years, in addition to the provision of benefits to the disabled, it was noted that they are involved in employment in all sectors of the economy in different regions of the country by social protection cooperatives.

Reports from the social security authorities provide information on the allocation of benefits to thousands of people with disabilities, but these reports do not specify the amount of benefits allocated to them. It is obvious that during the war there were many problems in the field of social protection.

During the war years, the majority of the population in need of social protection were mainly people with disabilities who had participated in the war. The organizations that were supposed to support them socially were social security cooperatives, cooperatives for the disabled, and their tasks were to plan the employment of people with disabilities in various sectors of the economy, the employment of war invalids. In the reports submitted by these organizations. There are facts about how many disabled people there were in Uzbekistan between 1941 and 1945, how many of them were war veterans and in which sectors they were employed. In January 1944 , the number of disabled people working in manufacturing industries was 34,466, while as of January 1945, their number was 52,057 . $[8,4]$

In addition, the records of this report indicate the percentage of people with disabilities working in manufacturing at the beginning of 1945 as follows: [9, 3]

131 out of 1037 people with group I disabilities, or 12.6 percent;

Out of 27,413 people with group II disabilities, 19,806 people or $72.2 \%$;

Of the 34,345 people with group III disabilities, 32,120 , or 93.5 percent, worked in manufacturing.

Evidence of social protection cooperatives, the co-operatives of the disabled, the social protection of the disabled, the provision of benefits to them, the state care of the disabled during the war are also mentioned in the reports of these organizations. However, during these years, the social protection of the disabled was limited to a certain amount of benefits, employment in the manufacturing sector, employment planning. In addition, such notes were made in documents relating to these years. It stipulates the abolition of benefits for people with disabilities employed in the manufacturing sector if they do not go to work or participate in production. The abolition of disability benefits is as follows: Disability benefits have been canceled for 725 
people who have been treated in hospitals, relocated to Uzbekistan from pre-war areas, who have not adapted to the local environment and refused to work for various reasons. [10, 3] It is obvious that social protection organizations have taken measures against people with disabilities in the above order for not coming to work, not being employed.

In 1941-1945, the attention paid to the issues of social protection of people with disabilities, who showed courage and perseverance in the fight against fascism, was very unsatisfactory. Our people have always adhered to the best traditions of Eastern spirituality, such as humanity, tolerance, care, in different historical periods, even in times of hardship. During the war against fascism, our people put into operation the factories and plants relocated to Uzbekistan, showed perseverance, true devotion, heroism, worked day and night and delivered the necessary products for the front. They have rendered the high tolerance and humanitarian assistance inherent in our people to the millions of people evacuated from the frontline areas. An example of the great humanity of our people during the Second World War can also be seen in the treatment of the disabled. Our people gave them all the help they could and supported them in every way.

During the years of the war against fascism, the people of Uzbekistan, despite the difficulties and hardships, have done a lot in various fields and achieved a number of economic and social achievements. In turn, our people have shown compassion and care to the population evacuated to the territory of the republic during the war, soldiers and officers who were wounded in battles, and people who became disabled as a result of the war.

Today's peaceful and happy life is directly due to the tireless selfless work of our ancestors, the high courage and perseverance in their struggle for peace.

\section{CONCLUSIONS}

"Even in the most difficult periods of the Second World War, our people have once again demonstrated such qualities as tolerance, solidarity, generosity and nobility. With their courage and heroic labors, they made an infinite contribution to the victory over fascism.

1. The Uzbeks did everything possible to help thousands of soldiers and officers recover. They also showed humanity and care for the disabled;

2. During the war against fascism, the social protection cooperatives operating in the country, the work carried out by cooperatives for the disabled were not organized in a properly planned manner;

3. The tasks of organizations that should provide social support to people with disabilities during the war years have been to plan the employment of people with disabilities in various sectors of the economy, the employment of war invalids;

4. In 1941-1945, the issues of social protection of people disabled due to the war were unsatisfactory;

One of the main goals is to pay tribute to the memory of the war veterans, to remember their memory, to honor our ancestors who endured the most difficult moments and horrors of the war, adhered to the principles of humanity and tolerance, showed courage and heroism on the front and behind the front.

\section{REFERENCES}

1. Speech by the President of the Republic of Uzbekistan Sh. Mirziyoyev at the solemn ceremony dedicated to the Day of 
Remembrance and Honor on May 9, 2019. // People's word. May 10, 2019

2. 2.3. Mirziyoev Sh.M. The consent of our people is the highest value given to our activities. Volume 2 T : "Uzbekistan". 2018.

3. Bobojonova D. The contribution of the people of Uzbekistan to the victory over fascism in the Second World War /I Looking to the past, issue 2. Volume 3, 2020.

4. Mirziyoev Sh.M. The consent of our people is the highest value given to our activities. Volume $2 \mathrm{~T}$ :: "Uzbekistan". 2018.

5. Central State Archive of the Republic of Uzbekistan. Fund R - 837, list № 32, compilation volume 4911, 30 - sheet.

6. Central State Archive of the Republic of Uzbekistan. Fund $\mathrm{R}-837$, list № 32, compilation volume 4961, 2,3,4 pages.

7. Abdurahmanova J.N. "The impact of World War II on the lives of the Greek people" (on the example of the Greeks deported to Uzbekistan). // "Looking to the past" Special issue, Tashkent - 2020. 79-82.

8. Abdurahmanova J.N. The policy of tolerance in Uzbekistan (in the case of Greeks). International Journal on Integrated Education. 2 (5). 212-214.

9. Yunusova Kh.E., Akramova F.A., Duschanov R., Abdurakhmonova J., Usarov U.A. Some comments on the monopoly of cotton in Uzbekistan in the 50-80s of the XX century and its impact on the environment.journal of critical reviews. volume 7 , issue 6. 2020. p.p.5153.

10. J.Abdurakhmanova, Sh.Jumaeva, U.Ismailov. The Importance of Shrinesin The Spiritual Life and Mentality of Uzbek People // International Journal of Psychosocial Rehabilitation, Vol. 24, Issue 09, 2020 r.r.-2389-2398.

11. Kholikulov, A., \& Nematov, O. N. (2020). The Role of The Principalities of The Kashkadarya Oasis In The Political History
Of The Bukhara Emirate In The XIX-Early XX Centuries. The American Journal of Social Science and Education Innovations, 2(11), 79-85.

12. Omonov, Q., \& Karimov, N. (2020). Importance of Ancestoral Heritage. The American Journal of Social Science and Education Innovations, 2(09), 196-202. 